\title{
Using Project-Based Learning to Develop English Story Writing and Reading Skills of Kindergarten
}

\author{
Dr. Jehan Mahmoud El-Bassuony \\ Assistant Professor, Department of Curriculum\& Instruction \\ Faculty of Education \\ Port Said University
}

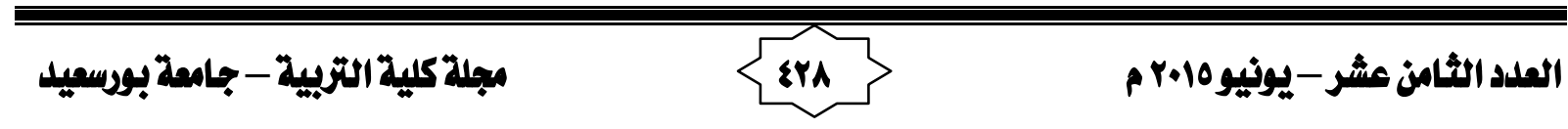




\begin{abstract}
The purpose of this study was to investigate the effectiveness of projectbased learning in developing kindergarten pre-service teachers' story writing and reading skills. The sample of the study consisted of thirty six second year pre-service teachers at Port Said Faculty of Kindergarten. The one group pre-post test quasi-experimental design was used. The instruments of the study included a story writing and reading test and the kindergarten pre-service teachers' satisfaction questionnaire. The results of the study revealed that project-based learning significantly developed the participants' story writing and reading skills. Furthermore, it proved to be acceptable by the participants.
\end{abstract}

Keywords: Project-based learning, story writing and reading skills, kindergarten pre-service teachers.

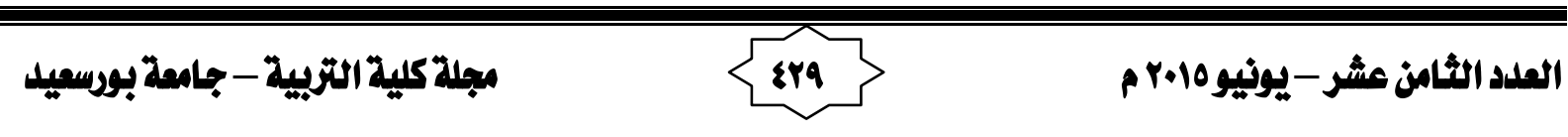




\section{Introduction}

Kindergarten plays an important role in helping children to acquire a variety of skills and abilities. Faculties of kindergarten pay increased attention to preparing teachers who are highly qualified to meet the needs of their future kindergarten children. Goldstein (2007), on his part, suggests that the purposes of kindergarten have been changing rapidly. Kindergarten teachers face many new requirements in addition to meeting children's needs across all developmental domains. As a result, kindergarten teachers have to master a variety of academic skills. Story writing and reading are valuable skills in both native and foreign language learning contexts. These skills are also of great importance for teachers since kindergarten children enjoy listening to stories read by their teachers.

Project based learning (PBL) is considered a powerful and motivating teaching method. It aims at problem solving in a collaborative environment over an extended period of time. It is a hands-on experience which starts from driving questions or problems that create activities and leads to the meaningful products at the end (Simpson, 2011). It also aims at developing learners' language skills through learning by doing. Foreign language learners often see the target language as something outside their world since they have no chance to employ the language learnt in the classroom or to use it outside the classroom. PBL allows learners to work together with hands-on experience in an authentic and meaningful context (Fried-Booth, 2002)

According to Foss, Carney, McDonald and Rooks (2007, p.4), projectbased instruction is a flexible methodology allowing multiple skills to be developed in an integrated, meaningful, and ongoing activity. It emphasizes learning through student-centered, interdisciplinary, and integrated activities in real world situations (Poonpon, 2011, p. 2). Since PBL is potentially motivating, empowering and challenging to language learners, it usually results in building learners' confidence, self-esteem, and autonomy as well as improving students' language skills, content learning, and cognitive abilities (Srikrai, 2008; Willie, 2001).

Meanwhile, preservice teachers should have the opportunity to practice and develop story writing and reading skills in order to be able to write suitable stories to their children, create big books and read them to their kindergarten children. These challenges draw the attention to the significance of story writing and reading skills and call for using different strategies to teach them to kindergarten pre service teachers. PBL, that has many advantages in the field of instruction, might hopefully improve story writing and reading of kindergarten pre-service teachers in Egypt. Finally, indicators of the success of PBL -based programs in one hand and the

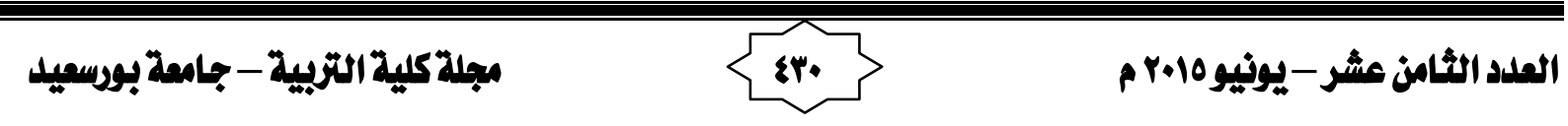


Using Project-Based Learning to Develop English Story Writing and Reading Skills of

shortage of empirical valid research in the promising area of story writing and reading, on the other hand, provided further rationales for conducting the present study.

\subsection{Context of the problem}

Being able to write and read a story to children is an important aspect of kindergarten pre-service teachers' language skills. The level of English language skills of kindergarten pre-service teachers was very low. This was revealed by the results of a previous study (Khodary, 2010), the views of both their professors in Port Said Faculty of kindergarten as well as their teaching practice supervisors. In addition, kindergarten pre-service teachers themselves complained of their low level of English reading and writing skills and the scarcity of opportunities to practice such skills. Therefore, there was an urgent need to develop kindergarten pre-service teachers' story writing and reading skills. In case they were not well prepared in these skills, their kindergarten children's level in English would be gradually worse. In other words, kindergarten pre-service teachers who lack necessary story writing and reading skills, would not be able to use stories to develop different English language skills of their future kindergarten children.

Moreover, the current Egyptian kindergarten programs did not provide kindergarten pre-service teachers with opportunities to practice story reading and writing skills in English. In order for kindergarten preservice teachers to be ready for such great responsibility of writing English stories and reading them to their kindergarten children in the classroom, they needed adequate preparation for developing these skills. In other words, they needed to master these skills to be a good model for their future kindergarten children while writing and reading English stories.

1.2 Statement of the problem

The problem of the study can be identified in the weak performance of kindergarten pre-service teachers concerning their English story writing and reading skills. Hence, this study sought to find an answer to the following main question:

What is the effectiveness of a treatment based on PBL in developing EFL kindergarten pre-service teachers' story writing and reading skills?

The following sub-questions were also answered:

1- What are the story writing and reading skills necessary to kindergarten pre-service teachers?

2- What are the features of the suggested project-based learning treatment for developing kindergarten pre-service teachers' story writing and reading skills?

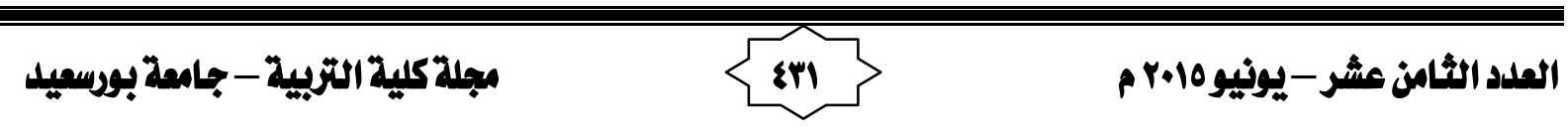


Using Project-Based Learning to Develop English Story Writing and Reading Skills of

3- How far is the treatment effective in developing kindergarten pre-service teachers' story writing skills?

4- How far is the treatment effective in developing kindergarten pre-service teachers' story reading skills?

5- How far are the participants satisfied with PBL?

1.3 Hypotheses of the study

Based on the discussion of literature and related studies, the following hypotheses were derived:

1- There would be statistically significant differences between the means of the scores of the subjects of the study group in the pre and post test in story writing skills in favor of the latter.

2- There would be statistically significant differences between the means of the scores of the subjects of the research group in the pre and post test of story reading skills in favor of the latter.

\subsection{Purpose of the study}

The purpose of the study was threefold:

1- Investigating the effectiveness of PBL in developing kindergarten preservice teachers' story writing skills.

2- Determining the effect of PBL on improving kindergarten pre-service teachers' story reading skills.

3- Examining the satisfaction level of kindergarten pre-service teachers with PBL.

\subsection{Significance of the study}

The significance of the study stems from the following considerations:

1- The test of story writing and reading, the kindergarten pre-service teachers' satisfaction questionnaire and the proposed treatment might be beneficial to kindergarten EFL researchers and curriculum designers.

2- The study might provide guidelines upon which further treatments may be designed to develop story writing and reading skills.

3- Kindergarten pre-service teachers might be able to use the treatment when they teach their future kindergarten children different English language skills.

\subsection{Delimitations of the study}

Since it was beyond the limits of a single study to consider a wide range of factors, this study was restricted to:

1- Selected story writing and reading skills that are required for kindergarten pre-service teachers.

2- A sample of thirty six second year pre-service teachers at Port Said Faculty of Kindergarten.

3- A limited duration for implementing the treatment (ten weeks).

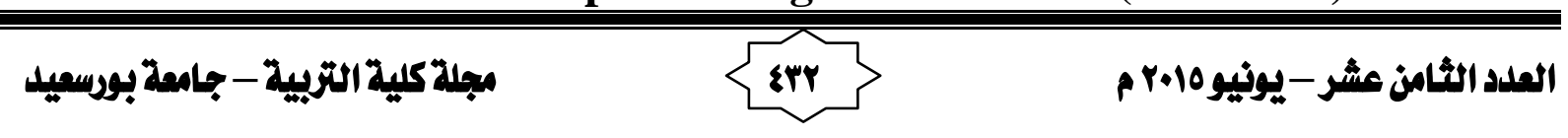


1.7 Definition of terms

Project-Based learning

Moss and Van Duzer (1998, p.1) defined PBL as an instructional approach that contextualizes learning by presenting learners with problems to solve or products to develop.

According to Fried-Booth $(2002$, p. 6), PBL is a means to create an endproduct in a real-world environment with confidence and independence. Project work is driven by the intrinsic needs of students who develop their own tasks individually or in small groups. This approach creates links between real-world language and language in textbooks.

PBL is an in-depth learning focusing on real-world problems and challenges that engage students who work as a team through meaningful activities resulting in an end product (Simpson, 2011).

In Patton's view (2012, p. 13), PBL refers to a method allowing students to design, plan, and carry out an extended project that produces a publicly exhibited output such as a product, publication, or presentation.

In the present study, PBL is defined as a motivating teaching method that uses authentic activities to develop story writing and reading skills of second year kindergarten pre-service teachers.

Story writing

Silio (2008, p. 11) points out that the primary purpose of narrative writing is to describe an experience, event, or sequence of events in the form of a story. It is typically a story written from the author's perspective and relies on personal experiences.

In the present study, story writing is defined as a genre of writing that kindergarten pre-service teachers can use to write stories to their kindergarten children focusing upon six elements: setting, characters, problem/conflict, organization, mechanics, and sentence structure.

Story reading

According to Gallets $(2005$, p. 10$)$, story reading refers to the oral presentation of a story by an individual to a person or group from the text of a picture book. Pictures printed on the pages of the book are made visible to the students at least periodically during the reading.

In the present study, story reading is defined as the ability of kindergarten pre-service teachers to read orally an English story to kindergarten children with fluency, accurate pronunciation, appropriate expression and body language.

\section{Review of literature and related studies}

The current study aims at developing kindergarten pre-service teachers' story writing and reading skills through designing and field-

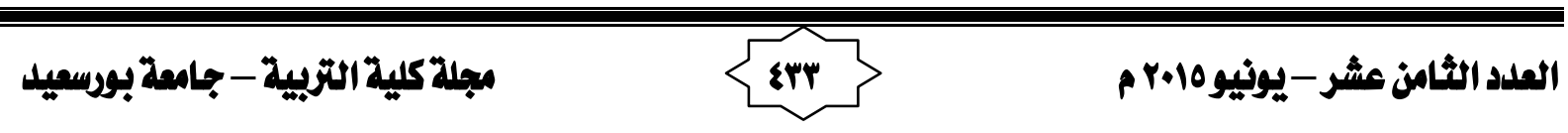


Using Project-Based Learning to Develop English Story Writing and Reading Skills of

testing a treatment based on PBL. The following section sheds more light on the main variables of this study: PBL and story writing and reading skills.

\subsection{Project-Based learning}

PBL is not a new approach in education. Beckett (2006) states that PBL can be traced back to the mid-1800s, and was first created by David Snedden who taught science in American agriculture classes. Later, in the early 1900s, PBL was further developed by William Heard Kilpatrick, John Dewey's student, and focused on the need for learners to have a purposeful activity (Muniandy, 2000). Elam and Nesbit (2012, p. 114) add that the basis of PBL was founded on Vygotskian Social Learning and Constructivist ideologies, which advocate that collaboration promotes intellectual growth.

According to Wrigley (1998), learners in PBL have the opportunity to construct knowledge by generating their projects based on their interests and individual differences. They make connections between their new knowledge and their existing knowledge and are able to apply them to similar settings. They learn in a meaningful context while creating the end product. As a result, PBL can achieve several goals, for example, the development of a positive attitude, critical judgment, teamwork, independent reasoning and study habits (Petrosino, 2007).

Solomon (2003, p. 10) explains that PBL is a process of learning that students are responsible for in their own education. Students work collaboratively to solve problems that are authentic, curriculum-based, and often interdisciplinary. Learners learn how to design their own learning process and decide what and where information can be collected. They analyse and synthesise the information then apply and present their new knowledge at the end.

Students have to present their newly acquired knowledge and a product which shows their learning. They are assessed throughout the process by peers and teacher. The teacher's role throughout is as a facilitator and advisor. Moreover, PBL develops useful research and study skills, such as the use of reference resources and modern technology, for example, computers, the internet and its powerful search engines, all of which are beneficial for lifelong learning (Markham, Mergendoller, Larmer, \& Ravitz, 2003; McGrath, 2003).

Authenticity plays an important role in PBL. Authentic activities are one of the main features of PBL as students have an opportunity to connect to real world situations while completing their projects (Markham et al., 2003). The PBL environment engages students in a meaningful learning process by using authentic activities as the reason for learning (Stoller, 2002). Authentic learning allows students to experience relevant and real-

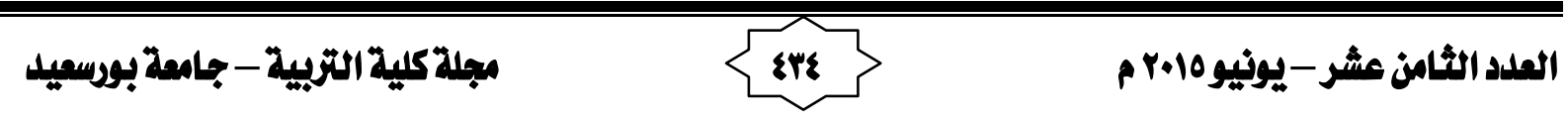


Using Project-Based Learning to Develop English Story Writing and Reading Skills of

world tasks. It makes their learning more meaningful by connecting prior knowledge to their current study.

Herrington and Herrington (2006, p. 2), on their part, emphasize that students in authentic learning environment are engaged in motivating and challenging activities that require collaboration and support. Students have real-life roles which are similar to the real world outside the class room and these necessitate teamwork, negotiation, and the use of problem-solving skills (Woo, Herrington, Agostinho, Reeves, 2007). As this learning is real and authentic, it follows that learners learn about the topic they feel they need to learn and when they need to learn it (Newell, 2003).

Furthermore, authentic tasks embedded in PBL have the potential to match the real-world contexts. Challenging topics should encourage students to communicate meaningfully and purposefully. After going through a complex process of in-depth learning, students then should have the opportunity to create authentic product that is directed towards their ultimate goal (Simpson, 2011).

Concerning benefits of PBL in language learning, Beckett and Slater (2005, p. 108) describe PBL as an effective way of engaging in simultaneous acquisition of language, content, and skills. PBL plays an important role in developing learners' target language for real-life purposes. It helps language students become more competent in the use of the target language and promotes learners' autonomy, learner centeredness, learner motivation and integrated skill practice (Sheppard \& Stoller, 1995).

It is clear that PBL can be a connection between using the target language in class and using the target language in authentic contexts outside the classroom. PBL is both process- and product-orientated (Stoller, 1997). Students have opportunities to use several skills (e.g., problemsolving, creativity, teamwork, as well as language) at different work stages, so the work and language skills are developed (Brunetti, Petrell, Sawada, 2003; Solomon, 2003).

PBL is different from traditional instruction because it emphasizes learning through student-centered, interdisciplinary, and integrated activities in real world situations (Solomon, 2003; Willie, 2001). In particular, PBL activities can be characterized as follows (Simpson, 2011; Srikrai, 2008): (a) focuse on content learning rather than on specific language patterns; (b) are student-centered so the teacher becomes a facilitator or coach; (c) encourage collaboration among students; (d) lead to the authentic integration of language skills and processing information from multiple sources; (e) allow learners to demonstrate their understanding of content knowledge through an end product (e.g., an oral presentation, a poster session, a bulletin board display, or a stage

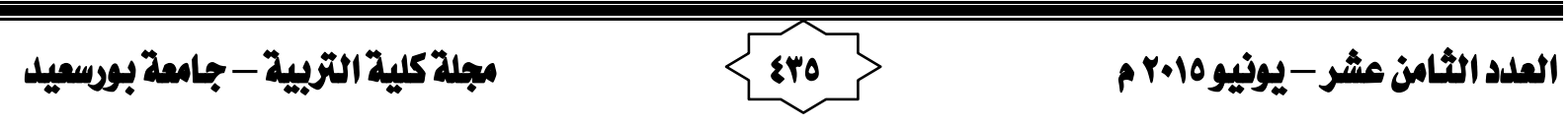


Using Project-Based Learning to Develop English Story Writing and Reading Skills of

performance); and (f) bridge using English in class and using English in real life contexts.

According to Hedge (2002), projects are extended tasks which usually integrate language skills by means of a number of activities. These activities combine in working towards an agreed goal and may include the following: planning; the gathering of information through reading, listening, interviewing, and observing; group discussion of the information; problem solving; oral and written reporting; and display. Project-based learning is similar to task-based learning to a certain degree, but it is larger than a single task.

More specifically, Fragoulis (2009) and Bell (2010) state that there are many benefits of implementing PBL in teaching English as Foreign Language. First, PBL gives contextual and meaningful learning for students. Second, PBL can create optimal environment to practice speaking English. Third, PBL can also make students actively engage in project learning. Forth, PBL enhances the students' interest, motivation, engagement, and enjoyment. Fifth, PBL promotes social learning that can enhance collaborative skills. Finally, PBL can give an optimal opportunity to improve students' language skill

Chayanuvat (2007), on her part, explored the implementation of PBL in a basic English course aiming to develop students' four skills for communicative purposes. Her questionnaire data revealed that more than $50 \%$ of the students were confident that PBL can help improve their English although most of them $(\mathbf{7 4 \%})$ were not ready for PBL in their English class. Moreover, Simpson (2011) indicated that PBL enhanced English major students' English language proficiency, their learning skills and self-confidence in an English for Tourism course.

Research has also shown that there are many benefits to using PBL in the language classroom such as gaining language proficiency, self-efficacy and self-esteem (Sritiwong, 2000; Sudrung, 2004; Termprayoon, 2002), using real-life language and experiencing language in meaningful life situations (Foss, Carney, McDonald, \& Rooks, 2007; Stanley, 2000), developing motivation, self-confidence (Finch, 2003; Johnson, 2003; Markham, et al., 2003; Stoller, 2006; Welsh, 2006) and improving the cognitive domain in second/foreign language learning (Hargrave, 2003; Helle, Tynjala, \& Olkinuora, 2006; McGrath, 2003).

In addition, Ke (2010) carried out a project-based college English course with students from the Geography and Tourism Departments. Results showed that PBL developed students' English oral skills, independent thinking, problem solving, and practical research skills. In the Egyptian context, Al-Neguly (2013) attempted a recent study that examined

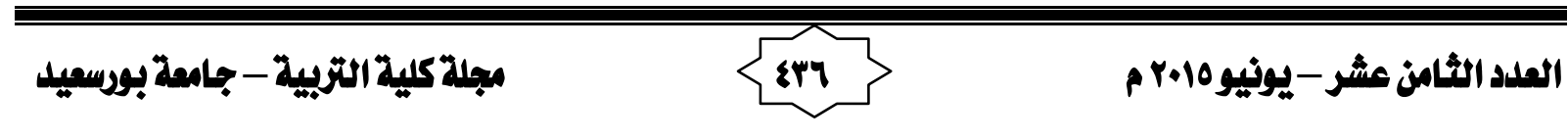


Using Project-Based Learning to Develop English Story Writing and Reading Skills of

the effectiveness of using PBL to develop EFL secondary stage students' writing and critical reading skills. Results indicated that the performance of the experimental group in both critical reading and writing skills improved significantly.

On these grounds, it becomes evident that PBL is a teaching methodology that allows the passion of learning to come to life and allows learners to see the need for knowledge and skills. It is potentially motivating, stimulating, empowering, and challenging. It usually leads to building student confidence, self-esteem, and autonomy as well as improving their language skills, content learning, and cognitive abilities.

\subsection{Story writing and reading skills}

Story writing is considered a type of narrative writing. According to $\mathrm{Li}$ (2000), narrative writing usually refers to storytelling. It is a form of writing that has great importance to students, especially those in elementary schools. The value of story writing is not limited to the domain of academics. Through writing stories, students can voice their ideas, express feelings, and explore imaginations. For many, writing a story is not just a way to entertain others, it can also be self-entertaining.

A story usually consists of some form of basic elements. According to Vallecorsa and deBettencourt (1997), the most common elements of a story include: (a) a plot, or a series of events; (b) the setting, which introduces the characters, time, and place in which the events occur; (c) the problem or conflict that the characters must face or overcome; (d) the goal, which represents the major desire of the main character; (e) an outcome that may be the point at which the conflict is resolved or the goal is reached; and (f) internal responses, which are the sub goals, thoughts, or feelings of a character leading to his/her actions.

Emphasis on story writing has various advantages for students. Martin and Marmo (1995) point out a number of beneficial reasons for focusing on improving the story-writing abilities of students with learning problems: (a) students can use their knowledge of story as a foundation to evaluate and appreciate many forms of literary works, such as plays, movies, TV shows, and stories; (b) story writing can become therapeutic when students are taught to give ideas and feelings and to develop plots that relate to their own experience; (c) when the emphasis is on content and ideas, students with learning disabilities are more likely to succeed and have fun with writing, thereby increasing their motivation to write.

A number of studies used different interventions to develop story writing skills. For example, Meyers (2008) investigated the effects of an imagery intervention on students' narrative writing skills. The results indicate that

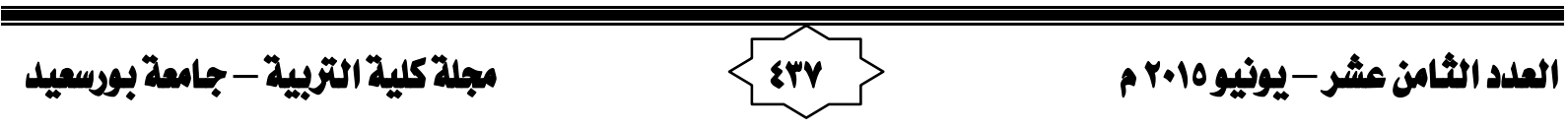


Using Project-Based Learning to Develop English Story Writing and Reading Skills of

students in the treatment group did not improve visualization skills or level of detail in narrative writing assignments when compared to the control group. However, there was a medium effect size supporting the use of imagery to improve students writing skills. Students in the imagery group also increased the number of words from pre to post measures when compared to the control group.

Silio (2008) examined the effects of word prediction and text-to-speech on the narrative composition writing skills of 6 , fifth-grade Hispanic boys with specific learning disabilities (SLD). This study demonstrated that word prediction alone or in combination assists students with SLD to write longer, improved-quality, narrative compositions.

Pennington (2010) evaluated the effects of simultaneous prompting (SP) and computer-assisted instruction (CAI) on the story writing responses of 5 males with autism, 6 to 10 years of age. The data indicated that SP and CAI were effective in improving the story writing skills of and increasing the number of sight words read by all 5 participants. In addition, all participants demonstrated maintenance and generalization of story writing skills.

Vokuja (2005) showed that the use of animation film in pre writing activity helped students explore the structural devices of story (plotlines, character development, setting, and theme). Retno Ayu (2007) revealed that the use of animation film or movie (her film's title was Brother Bear) in writing class developed students' ability in narrative text, especially in content and grammar.

It is common for teachers to read stories to young elementary school students in class. Storybook reading is widely recommended in educational literature (Kaderavek, \& Justice, 2002; Rubin \& Wilson, 1995). Morrow (1996, p. 56) states that several experimental studies that have sought out the effects of storybook reading as an everyday classroom routine on child development found that children in the treatment groups produce higher scores in the areas of vocabulary, story comprehension, and decoding that do the children in the groups who are not read to.

Though it is tempting to think of storybook reading as a single specific type of activity, sometimes shared storybook experiences can take on a variety of different forms. By inviting children to listen, savor, chorally read, envision images, engage in creative movement, and manipulate literary language during whole group, small group, or center activities, teachers not only provide opportunities for children to develop an appreciation for literature, they also support children's ability to think about and explore how language systems work (Labbo \& Field, 1996, p. 618).

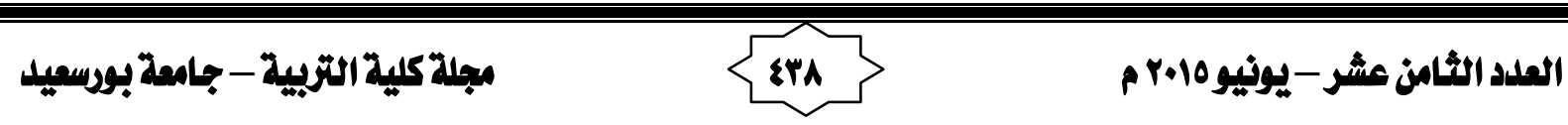


Baumann and Kame'enui (2004, p. 48), on their part, believe that shared storybook reading involves teachers engaging children in discussion of the story by activating prior knowledge, eliciting responses about story elements, linking story themes to children's own experiences, and facilitating story recall. Story reading clearly is not just for fun, it also helps children learn to be better users of language, helps children learn to search for meaning, has an impact on children's overall academic performance, and may also help children to become more understanding citizens (Gallets, 2005, p. 9).

In Collins' view (2005), childhood story experiences, both at home and in school, are significant, not only in childhood but in adults' lives as well. Memories of being read to by a teacher are often positive and reassuring. The significance of reading aloud to children should not be underestimated, whether the children are of pre-school or primary-school age. When a teacher reads a novel to a class of children, she brings the text alive and makes the act a shared experience for all. The children are pulled into the narrative through the sheer enjoyment of listening. Barrs and Cork (2001, p. 216) argue that "the giving of voice and breadth to a text, instead of leaving it inertly as marks on a page, is an essential way of communicating the full range of its force and meaning."

Reading aloud is closely related to storytelling if the performance is expressive. A three years old girl described her student teacher while reading aloud stating that she's got lots of expression and she's sort of dragging me into the story (Collins, 2005, p. 13). Regular reading aloud becomes a community event as readers draw out, from each other, thoughts and responses to the text (Chambers, 1993). Barrs and Cork (2001) add that through this exchange a community of readers is established and a shared knowledge of the text is developed. This social act allows for the content of the story to be explored, as well as the language and voice of the author. When read aloud in class, texts gain authenticity from the act itself and also from the context of the educational setting (McDonald, 2004).

Gallets (2005) compared the effects of storytelling and story reading. The sample consisted of kindergarten, first, and second grade students. Half the students were read stories aloud, the other half were told the same stories by a storyteller. Data were collected regarding students ability to recall facts they had heard, as well as students skill in using formal story elements. The students' interpretations of story meaning were also examined. Students in both the reading and storytelling groups improved on most measures. However, on some measures, notably those regarding recall ability, students in the storytelling group improved more than students in the reading group.

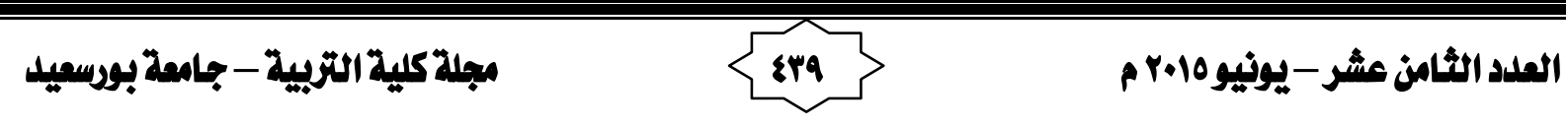


To sum up, the importance of story writing and reading as necessary tools for language proficiency and a basic requirement for kindergarten teachers have been emphasized. Many educationalists and researchers in different contexts tried to use different strategies to develop the varied story writing and reading skills. Providing many opportunities for students to develop these skills is of great importance. PBL has the potential to develop story writing and reading skills of kindergarten pre service teachers.

3. Methodology

\subsection{Participants}

Participants of the present study were second-year students studying at faculty of kindergarten, Port Said University. The thirty six female students represented a one study group. The average age of the participants was (20.03) years.

\subsection{Design of the study}

The researcher used the one group pre-post test quasi-experimental design. Before the treatment, the responses of the students on story writing and reading skills test were collected, analyzed, and scored. Then the treatment was carried out. The duration of the instruction was 10 weeks, one session per week. At the end of the instruction, the same test and the kindergarten pre-service teachers' satisfaction questionnaire were applied to determine whether the story writing and reading skills have improved as a result of using PBL as well as the satisfaction level of students. The treatment was applied in the second term of the academic year 2014-2015.

3.3 Instruments of the study

Two instruments were used in this study: (available with the researcher upon request)

A- The story writing and reading skills test.

B- The kindergarten pre-service teachers' satisfaction questionnaire.

3.3.1 The story writing and reading skills test

The story writing and reading skills test was constructed in the light of prior literature on story writing and reading skills tests. The story writing and reading skills test (Appendix: A) was prepared by the researcher to assess kindergarten pre-service teachers' story writing and reading skills before and after the treatment. The test measured six story writing sub skills: setting, characters, problem/conflict, organization, mechanics, and sentence structure. It also assessed four story reading sub skills: fluency, pronunciation, expression and body language. The final version of the test, modified according to the feedback from the three jury members, consisted of two tasks. In the first task, students had to write two or three sentences under each picture to make a story. As for the second task, students had to read a story to a group of kindergarten children. The first task was scored

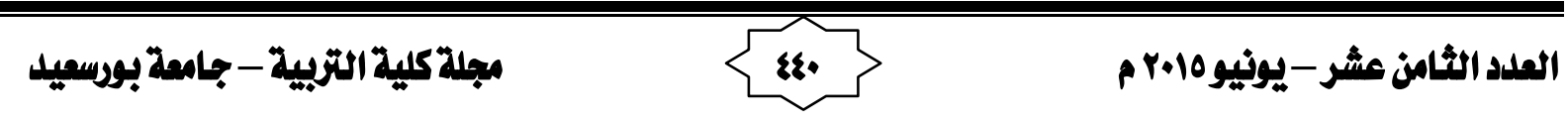


Using Project-Based Learning to Develop English Story Writing and Reading Skills of

out of (24) and the second one was scored out of (16) based on the story writing and reading skills rubric (Appendix: B). So, the test was scored out of $(40)$.

A four level rubric was developed by the researcher to grade the participants' responses to the tasks in the story writing and reading skills test before and after the treatment. Each level in the rubric was given an estimated value. The first level (apprentice) was assigned (1). The second level (basic) was assigned (2). The third level (learned) was assigned (3). The fourth level (exemplary) was assigned (4). Using the rubric enabled the researcher to get detailed profiles of the participants' responses to tasks in the test.

For ensuring objectivity of scoring, two raters scored the test using the rubric. Inter-rater reliability was estimated by calculating the correlation coefficient between two raters' scoring of the test of $\mathbf{3 0}$ kindergarten preservice teachers (not included in the main treatment). The correlation coefficient between the raters' scores was 0.92 . The rubric was then used to grade the subjects' responses in the pre and post tests.

Validity of the story writing and reading skills test

To measure test content validity, the first version of the test was presented to three EFL jury members to evaluate the test in terms of accuracy, arrangement and number of questions, difficulty level of the questions, and the suitability of the test for the kindergarten pre-service teachers' proficiency level. Their opinions were taken into consideration when preparing the final version. In addition, the calculated intrinsic validity for the story writing and reading skills test was 0.95 . Therefore, the test was considered valid for the purposes of the current study.

Reliability of the story writing and reading skills test

The test was administered to 32 kindergarten pre-service teachers in Port Said Faculty of Kindergarten (not included in the main treatment of the study). Cronback's Alpha (Marascuilo, 1971; Payne, 1997) was used to calculate the reliability coefficient of the test. The calculated reliability coefficient was 0.89 . Thus, the test is reliable to be used in assessing kindergarten pre-service teachers' story writing and reading skills.

3.3.2 The kindergarten pre-service teachers' satisfaction questionnaire

This questionnaire was employed to determine the satisfaction level of kindergarten pre-service teachers about using PBL to develop their story writing and reading skills. It consists of three parts including: (1) the PBL treatment as a whole, (2) general evaluation of the instructor, and (3) the different components of the treatment. Ten items were devoted to each part. A five-point Likert-type scale, from (1) strongly disagree to (5)

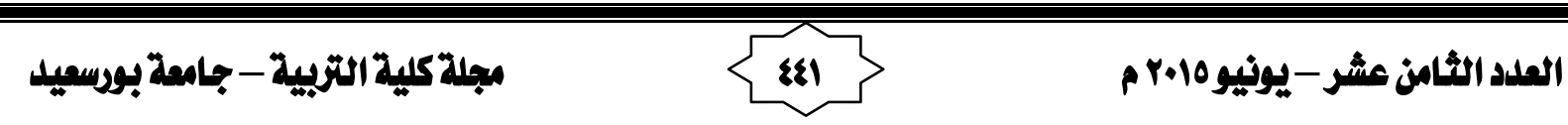


strongly agree, was used to assess what the students think about the different aspects of the treatment (Appendix: C).

Validity and reliability of the questionnaire

The first version of the questionnaire was presented to three EFL jury members to modify, omit or add any items they considered important/unimportant. Based on their suggestions, certain items were omitted and other items were paraphrased. The final version of the questionnaire included 30 items. To measure its reliability, the questionnaire was administered twice to the study group. The first administration was just after the treatment and the second one was two weeks later. The correlation coefficient between the two administrations was 0.84 . Thus, the questionnaire was reliable to be used in assessing satisfaction level of kindergarten pre-service teachers about using PBL to develop their story writing and reading skills.

3.4 The treatment

\subsubsection{Aim of the treatment}

This PBL treatment aimed at developing kindergarten pre-service teachers' story writing and reading skills.

\subsubsection{Objectives of the treatment}

By the end of this treatment, kindergarten pre-service teachers were expected to:

- write English stories that are suitable to their kindergarten children's linguistic level.

- write English stories focusing on six elements: setting, characters, problem/conflict, organization, mechanics, and sentence structure.

- use their stories to create big books that are clear and attractive to children.

- read their English stories orally with expression, fluency, accurate pronunciation and body language.

\subsubsection{Content and duration of the treatment}

The treatment comprised ten sessions. Students had one session per week and each session took two hours. An orientation session was used at the beginning of the treatment to introduce the five stages of process writing, the importance of project work and the different stages of PBL. The following nine sessions were devoted to practising the story writing and reading skills in three projects. Each project included three stages: write a story, create a big book, and read the story orally.

Moreover, two repeated reading strategies were used: a) paired reading, b) performance reading. In paired reading, pairs of students took turns reading and rereading the same story from a big book to each other providing support and guidance. In performance reading, a group of

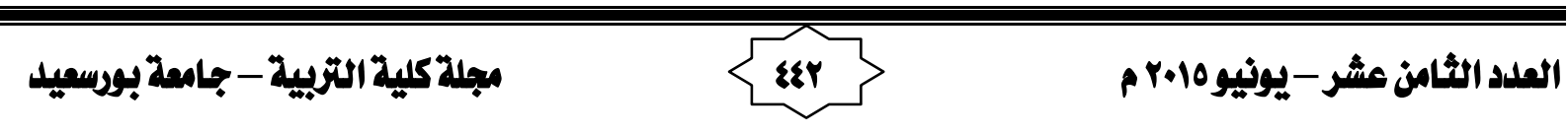


students practiced reading a story from a big book to prepare for a performance of the story. These two strategies helped them gain proper and expressive reading. In addition, the procedures used in each session were as follows:

\subsubsection{Procedures of the session}

- T. asked Ss to select a title for a story and drew a story map to summarize setting, characters, problem, and events.

- Ss were divided into groups and each group selected a topic for their stories and drew a story map about it.

- T. wrote the first draft of the story using her story map.

- T. asked each group to use their maps to write their first drafts

- Ss were asked to revise their drafts using revising checklist to focus upon organization and clarity of ideas.

- Ss in each group exchanged their drafts with another group for modification.

- Ss were asked to use the editing checklist to focus upon mechanics and sentence structure.

- Each group was asked to write their stories for evaluation. Students had to follow the stages of process writing to write a story as a home assignment.

- At the beginning of the following session, $T$. commented on the most common errors in students' writings.

- T. presented the features of big books concerning size, drawings and colours. - T. showed students how to create big books using their stories.

- Ss were divided into groups and they were given hard paper and colours to create their big books

- Big books were evaluated based on the size, clarity of the print and the drawings.

- Ss had to create their big books using their previously written stories as a home assignment.

- At the beginning of the third session, T. commented on students' big books.

- T. read a story using a big book focusing on expression, pronunciation, fluency and body language.

- Pairs of Ss took turns reading and rereading the same story from a big book to each other.

- Ss were divided into groups and each student had to read a part of the story to her colleagues as if they were her kindergarten children.

- T. observed students to clarify any confusing parts in their readings and record the most common errors.

- T. asked individual students to read their stories orally.

- T. provided remedial exercises to overcome repeated errors.

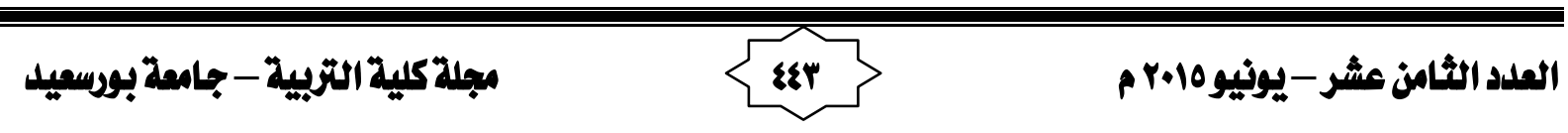


- Ss had to record their reading of the stories as a home assignment.

\subsubsection{Evaluation}

The evaluation techniques used in the treatment consisted of both quantitative and qualitative evaluation. Quantitative evaluation was divided into formative and summative evaluation:

- Formative evaluation

It was used for the purpose of assessing the progress of kindergarten pre-service teachers in developing story writing and reading skills as well as providing the necessary feedback that can help them monitor their own progress. The researcher evaluated students' writing herself throughout implementing the treatment. She collected some of their home assignments at the end of each session and wrote comments about them to her students. The students received a grade on their home assignments and also had to compare their initial writings / readings at home with their final reading with their partners concerning different story writing and reading sub skills.

- Summative evaluation

It included the administration of the pre-post story writing and reading skills test to investigate the effectiveness of the program in developing English story writing and reading skills of the study group.

As for qualitative evaluation, in every session the teacher used to collect some of the students' writings or oral reading records to comment on them. The teacher focused on the good points as well as the weak ones. The teacher kept written records for each student. These records included the date and the comments of the teacher on a student's piece of writing or oral reading. These records gave the teacher a clear idea of students' progress. For more details about the treatment and the handouts see (Appendix: D\&E).

\section{Results and discussion}

\subsection{Results}

The results of the study will be presented in terms of the study hypotheses as follows:

Hypothesis one: There would be statistically significant differences between the means of the scores of the subjects of the study group in the pre and post test in story writing skills in favor of the latter.

The " $t$ " test for paired samples was used to find out the extent to which subjects' oral reading fluency skills have developed throughout the program. The results of the " $t$ " test proved to be statistically consistent with the above stated hypothesis as shown in table (1).

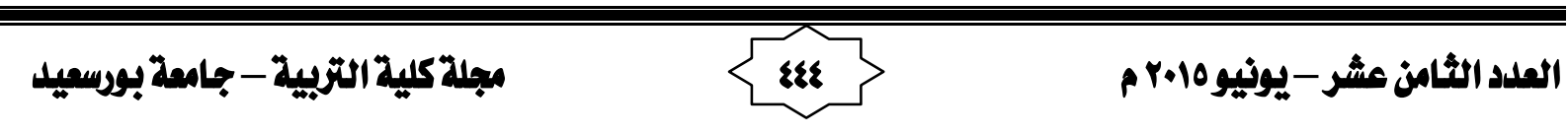




\section{Table (1)}

" $t$ " test of the pre and post story writing skills test

\begin{tabular}{|c|c|c|c|c|c|c|}
\hline Sub skills & & $\mathbf{N}$ & Mean & SD & T-test & P-value \\
\hline \multirow{2}{*}{ Setting } & Pre-test & \multirow{2}{*}{36} & 1.50 & 0.51 & \multirow{2}{*}{8.81} & \multirow{2}{*}{0.001} \\
\hline & Post-test & & 2.81 & 0.75 & & \\
\hline \multirow{2}{*}{ Characters } & Pre-test & \multirow{2}{*}{36} & 1.42 & 0.50 & \multirow{2}{*}{8.92} & \multirow{2}{*}{0.001} \\
\hline & Post-test & & 2.81 & 0.86 & & \\
\hline \multirow{2}{*}{ Problem } & Pre-test & \multirow{2}{*}{36} & 1.39 & 0.49 & \multirow{2}{*}{8.15} & \multirow{2}{*}{0.001} \\
\hline & Post-test & & 2.78 & 0.83 & & \\
\hline \multirow{2}{*}{ Organization } & Pre-test & \multirow{2}{*}{36} & 1.31 & 0.47 & \multirow{2}{*}{10.38} & \multirow{2}{*}{0.001} \\
\hline & Post-test & & 2.69 & 0.71 & & \\
\hline \multirow{2}{*}{ Mechanics } & Pre-test & \multirow{2}{*}{36} & 1.25 & 0.44 & \multirow{2}{*}{13.26} & \multirow{2}{*}{0.001} \\
\hline & Post-test & & 3.14 & 0.83 & & \\
\hline \multirow{2}{*}{$\begin{array}{l}\text { Sentence } \\
\text { structure }\end{array}$} & Pre-test & \multirow{2}{*}{36} & 1.42 & 0.50 & \multirow{2}{*}{9.07} & \multirow{2}{*}{0.001} \\
\hline & Post-test & & 2.83 & 0.81 & & \\
\hline \multirow{2}{*}{$\begin{array}{c}\text { Story } \\
\text { writing skills } \\
\text { test }\end{array}$} & Pre-test & \multirow{2}{*}{36} & 8.28 & 1.09 & \multirow{2}{*}{24.31} & \multirow{2}{*}{0.001} \\
\hline & Post-test & & 17.06 & 2.11 & & \\
\hline
\end{tabular}

As shown in table (1), the estimated " $t$ " value for the overall story writing skills was significant at 0.001 level. This indicates that there are statistically significant differences between the mean scores of the subjects in the pre-post test in favour of the post test score. Therefore, there is enough evidence to support hypothesis one.

Hypothesis two : There would be statistically significant differences between the means of the scores of the subjects of the research group in the pre and post test of story reading skills in favor of the latter.

In order to verify the validity of this hypothesis, " $t$ " test for paired samples was used. The results proved that there were statistically significant difference between the pre- post story reading skills test mean score of the subjects in the four sub skills of story reading. The results of the " $t$ " test proved to be statistically consistent with the above stated hypothesis as shown in table (2).

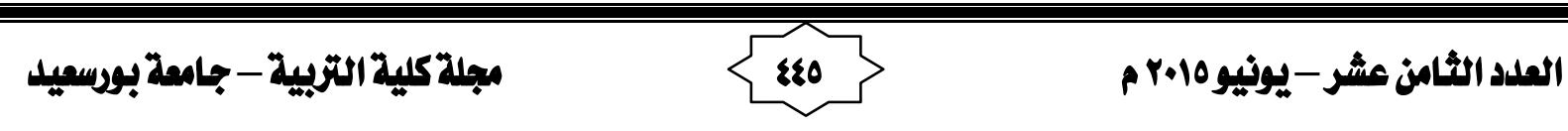




\section{Table (2)}

" $t$ " test of the pre and post oral reading fluency test

\begin{tabular}{|c|c|c|c|c|c|c|}
\hline Sub skills & & $\mathbf{N}$ & Mean & SD & T-test & $\begin{array}{c}P- \\
\text { value }\end{array}$ \\
\hline \multirow{2}{*}{ Expression } & Pre-test & \multirow{2}{*}{36} & 1.44 & 0.50 & \multirow{2}{*}{11.07} & \multirow{2}{*}{0.001} \\
\hline & Post-test & & 3.00 & 0.72 & & \\
\hline \multirow{2}{*}{ Pronunciation } & Pre-test & \multirow{2}{*}{36} & 1.33 & 0.48 & \multirow{2}{*}{9.89} & \multirow{2}{*}{0.001} \\
\hline & Post-test & & 2.78 & 0.72 & & \\
\hline \multirow{2}{*}{ Fluency } & Pre-test & \multirow{2}{*}{36} & 1.22 & 0.42 & \multirow{2}{*}{10.20} & \multirow{2}{*}{0.001} \\
\hline & Post-test & & 2.61 & 0.64 & & \\
\hline \multirow{2}{*}{ Body language } & Pre-test & \multirow{2}{*}{36} & 1.44 & 0.50 & \multirow{2}{*}{10.38} & \multirow{2}{*}{0.001} \\
\hline & Post-test & & 2.83 & 0.77 & & \\
\hline \multirow{2}{*}{$\begin{array}{l}\text { Story reading } \\
\text { skills test }\end{array}$} & Pre-test & \multirow{2}{*}{36} & 5.44 & 0.91 & \multirow{2}{*}{17.97} & \multirow{2}{*}{0.001} \\
\hline & Post-test & & 11.22 & 1.68 & & \\
\hline
\end{tabular}

To sum up, table (2) shows that there were statistically significant differences at 0.001 level between the mean scores of the subjects in the prepost story reading skills in favour of the post story reading skills scores for the overall story reading skills as well as the four sub skills.

Table (3)

Results of the kindergarten pre-service teachers' satisfaction questionnaire Frequencies and percentage of the students' responses

\begin{tabular}{|c|c|c|c|c|c|c|c|}
\hline \multirow[b]{2}{*}{ Categories } & \multicolumn{6}{|c|}{ Frequencies } & \multirow[b]{2}{*}{$\%$} \\
\hline & 1 & 2 & 3 & 4 & 5 & $\begin{array}{c}\text { Highest } \\
\text { Rank } \\
\text { Orders }\end{array}$ & \\
\hline \multirow{10}{*}{$\begin{array}{c}\text { PBL treatment as a } \\
\text { whole }\end{array}$} & - & - & 1 & 4 & 31 & 35 & 97.22 \\
\hline & - & 2 & 4 & 5 & 25 & 30 & 83.33 \\
\hline & - & 1 & 4 & 8 & 23 & 31 & 86.11 \\
\hline & $\mathbf{1}$ & 2 & 3 & 8 & 22 & 30 & 83.33 \\
\hline & - & 1 & 2 & 15 & 18 & 33 & 91.66 \\
\hline & - & - & 3 & 13 & 20 & 33 & 91.66 \\
\hline & - & 2 & 4 & 8 & 22 & 30 & 83.33 \\
\hline & - & 2 & 2 & 11 & 21 & 32 & 88.88 \\
\hline & - & 1 & 4 & 8 & 23 & 31 & 86.11 \\
\hline & - & 2 & 3 & 12 & 19 & 31 & 86.11 \\
\hline General evaluation of & - & - & 4 & 8 & 24 & 32 & 88.88 \\
\hline
\end{tabular}

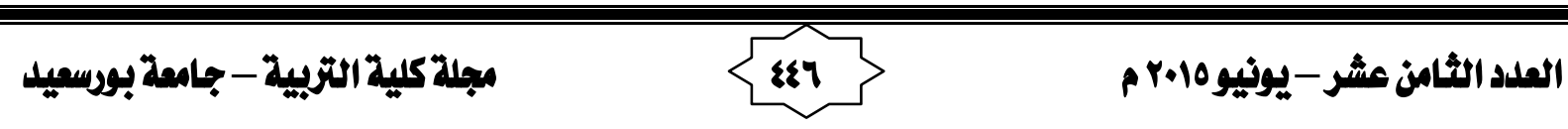


Using Project-Based Learning to Develop English Story Writing and Reading Skills of

Categories

Table (3) continued

the instructor

\begin{tabular}{|c|c|c|c|c|c|c|}
\hline \multicolumn{6}{|c|}{ Frequencies } & \multirow[b]{2}{*}{$\%$} \\
\hline 1 & 2 & 3 & 4 & 5 & $\begin{array}{c}\text { Highest } \\
\text { Rank } \\
\text { Orders }\end{array}$ & \\
\hline- & - & 1 & 15 & 20 & 35 & 97.22 \\
\hline- & - & - & 14 & 22 & 36 & 100 \\
\hline- & - & - & 13 & 21 & 34 & 94.44 \\
\hline - & - & 2 & 12 & 22 & 34 & 94.44 \\
\hline- & - & 1 & 16 & 19 & 35 & 97.22 \\
\hline- & 1 & 2 & 15 & 18 & 33 & 91.66 \\
\hline- & - & 2 & 12 & 22 & 34 & 94.44 \\
\hline- & - & 2 & 11 & 23 & 34 & 94.44 \\
\hline- & - & 1 & 13 & 22 & 35 & 97.22 \\
\hline- & 1 & 2 & 14 & 19 & 33 & 91.66 \\
\hline- & 2 & 4 & 12 & 18 & \begin{tabular}{|l|}
30 \\
\end{tabular} & 83.33 \\
\hline- & 2 & 3 & 11 & 20 & 31 & 86.11 \\
\hline 1 & 2 & 4 & 8 & 21 & 29 & 74.35 \\
\hline- & 2 & 2 & 15 & 17 & 32 & 88.88 \\
\hline 1 & - & 3 & 12 & 20 & 32 & $\mathbf{8 8 . 8 8}$ \\
\hline- & 2 & 4 & 14 & 16 & 30 & 83.33 \\
\hline- & - & 3 & 14 & 19 & 33 & 91.66 \\
\hline- & - & 5 & 13 & 18 & 31 & 86.11 \\
\hline- & 1 & 3 & 10 & 22 & 32 & 88.88 \\
\hline
\end{tabular}

The different components of the

PBL treatment

Table (3) reports the frequencies and percentage of the students' responses on the questionnaire. Most of their responses were in the highest rank orders. The average of the students' responses within the highest ranks were $96.66 \%$ for evaluating the treatment as a whole, $95 \%$ for evaluating the instructor, and $86.32 \%$ for the different components of the treatment. There was a general consensus that using PBL was a positive experience.

4.2 Discussion

Concerning the overall story writing and reading skills, the positive results of this study support the findings of other studies like Al-Neguly (2013), Chayanuvat (2007) and Simpson (2011). This result might be due to the fact that PBL is motivating. Students were encouraged to write and read stories because they enjoyed it. PBL provided students with the opportunity to learn in an authentic and challenging environment. They learned how to design, carry out, and evaluate a project that requires sustained effort over a significant period of time both individually and in groups. The frequent feedback from peers, groups and the teacher helped

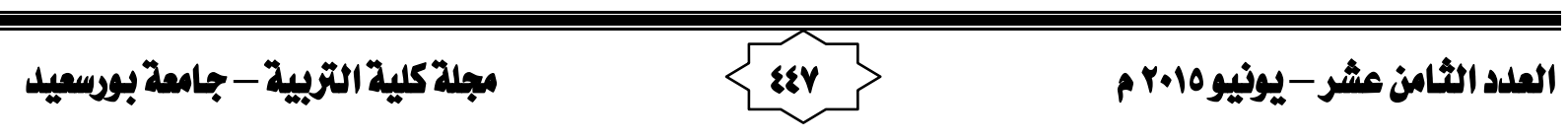


them monitor their own progress, So, it was much easier for them to deal with hands-on activities and use authentic resources .

Concerning story writing skills, students' progress might be due to certain factors: (a) group work immersed students in writing by providing a great deal of interaction during writing, (b) using the five stages of process writing helped students to focus on specific elements in each stage, (c) using collaborative learning techniques such as group writing, peer revising and peer editing helped them concentrate on specific writing skills ,(d) knowing their audience and providing real world purposes for writing motivated students to write more effectively with enthusiasm, (e) publishing students' works in the form of big books enhanced their writing performance and generated a deeper appreciation for story writing, and (f) sharing the responsibility of writing during group work increased students' interests in story writing.

In addition, students' progress in story reading skills might be attributed to different factors. First, the intensive practice of different story reading skills during oral reading of stories encouraged students to exert a lot of efforts to perfect their readings. Second, modeling and feedback were natural components of story reading in groups. Third, the sense of humor that prevailed during performance reading helped students feel secure and increased their self confidence. Fourth, the non threatening environment motivated students to participate in story reading without fear of evaluation. Fifth, the paired repeated reading strategy provided an opportunity for students to correct each other's errors in a non-threatening environment and to reflect on their reading improvement.

Furthermore, students perceived PBL as highly interesting and useful. All 36 students responded that they felt that PBL helped them develop their story writing and reading skills. In addition, results indicated that students appreciated ongoing evaluation methods and the way they get feedback in supportive and non-threatening learning environment that helped them to participate actively in story writing and reading tasks. Analyzing the students' responses also indicated that they appreciated the non- traditional roles of the instructor like being enthusiastic, committed, active, and supportive.

To sum up, the results of the questionnaire demonstrated favorable responses towards the use of the PBL treatment. Students found the treatment worthwhile and helped them develop their story writing and reading skills. They also indicated that $\mathrm{PBL}$ treatment should be used for other students.

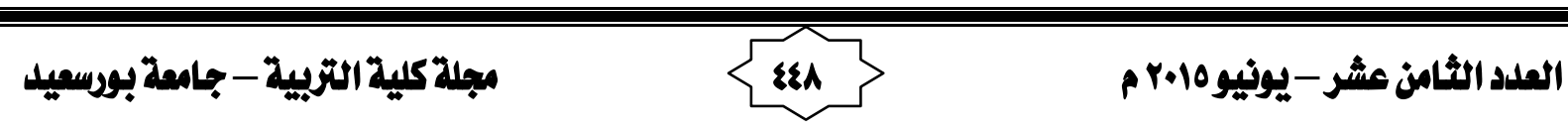


5. Conclusion, recommendations, and suggestions for further research

It is important to mention that the results of the study are limited by the sample size, the characteristics of the subjects, the length of the study and the selected story writing and reading skills used in the study. Within these limitations, it can be concluded that the treatment based on PBL is effective in developing kindergarten pre-service teachers' story writing and reading skills as well as the sub skills. These results support the indicators of success that PBL studies revealed in other contexts (Helle, et al., 2006; Foss, Carney, McDonald, Rooks, 2007; Stoller, 2006; Sudrung, 2004; Termprayoon, 2002; Welsh, 2006). To sum up, the results of the study can provide the basis for many other treatments based on PBL to develop different skills in different language learning contexts.

\subsection{Recommendations}

Based on the results of this study and the above mentioned conclusions, the following recommendations seem pertinent: (a) pre-service kindergarten teachers should be encouraged to write a story, create a big book, and read the story orally to children to develop English language skills of their future kindergarten children; (b) story writing and reading instruction should be a part of English courses in kindergarten faculties; (c) PBL should be used in teaching story writing and reading skills to school students; (d) more attention should be given to English story writing and reading skills in Egyptian kindergartens; and (e) PBL should be included in university courses as an authentic and motivating teaching method.

5.2 Suggestions for further research

Within the limitations of the present study as well as the results being achieved, the following areas are suggested for further research:

1- Conducting studies to use programs based on PBL with EFL learners at various educational levels and in different language learning contexts.

2- More research is needed to examine the effectiveness of programs based on PBL in developing different language skills.

3- More research is needed to examine different programs that develop story writing skills (setting, characters, problem/conflict, organization, mechanics, and sentence structure) of kindergarten pre service teachers.

1- Conducting studies to examine different programs that could improve story reading skills (fluency, pronunciation, expression and body language) of kindergarten pre-service teachers.

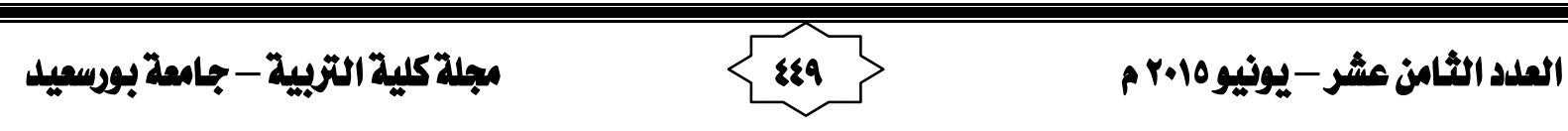




\section{References}

1. Abdel Rahim, S. (2001). The effect of communication strategies and risk-taking on oral fluency. Occasional papers issued by CDELT, 33, 200-231

2. Allington, R. (2001). What Really Matters for Struggling Readers: Designing Research Based Programs. New York: Addison-Wesley.

3. Al-Neguly, W. (2013). Using project- based learning to develop EFL secondary stage students' writing and critical reading skills. Unpublished doctoral dissertation, Faculty of Education, Mansoura University.

4. Arone, A., \& Arone, A. (2002). Statistics for the behavioral and social sciences: A brief course. Upper Saddle River, NJ: Pearson Educational.

5. Barrs, M. \& Cork, V. (2001).The reader in the writer. London: CLPE.

6. Barton, B. (1986). Tell me another: Storytelling and reading aloud at home, at school and in the community. London: Heinemann Education; Canada: Pembroke.

7. Baumann, J. F., \& Kame'enui, E. J. (2004). Vocabulary instruction. New York, NY: Guilford.

8. Beckett, G. H. (2006). Project-based second and foreign education: Theory, Research, and Practice. In G. H. Beckett \& P. C. Miller (Eds.), Project-Based Second and Foreign Language Education: Past, Present, and Future (pp. 3- 18). USA: Information Age Publishing.

9. Beckett, G. H., \& Slater, T. (2005). The Project Framework: a tool for language, content, and skills integration. ELT Journal, 59(2), 108-116.

10.Bell, S. (2010). Project-based learning for the 21th century: skill for the future. The Cleaning House, 83, 39-43.

11.Brunetti, A. , \& Petrell, R. , \& Sawada, B. (2003). Team project-based learning enhances awareness of sustainability at the University of British Columbia, Canada. International Journal of Sustainability in Higher Education, 4, 210.

12.Chambers, A. (1993) Tell me: Children, reading \& talk. Stroud: Thimble Press.

13. Chayanuvat, A. (2007). Developing a PBL English course: A discovery journey.

a. Paper presented at the Third International Conference on PBL, Nakhon Si Thammarat, Thailand. Retrieved September 26, 2013, from http://pbl2.wu.ac. th/conference 
14.Collins, F. (2005). "She's sort of dragging me into the story!'Student teachers' experiences of reading aloud in Key Stage 2 classes. Literacy, 39(1), 10- 17.

15.Elam, J., \& Nesbit, B. (2012). The effectiveness of project-based learning utilizing Web 2.0 tools in EFL. The JALT CALL Journal, 8(2), 113-127.

16.Finch A. (2003). Projects for Special Purposes: A New Look at Freshman English. Retrieved January 5, 2015, from http ://www. finchpark. com/arts/psp/index.htm

17.Foss, P., Carney, N., McDonald, K., \& Rooks, M. (2007). ProjectBased Learning Activities for Short-Term Intensive English Programs. Asian EFL Journal, 23(2), 1-19.

18.Fragoulis, I. (2009). Project-Based Leaning in the Teaching of English as a Foreign Language in Greek Primary. English Language Teaching, 2(3), 113-117.

19.Fried-Booth, D. (2002). Project Work. Oxford: Oxford University Press.

20.Gallets, M. (2005). Storytelling and Story Reading: A Comparison of Effects on Children's Memory and Story Comprehension. Unpublished master's thesis, East Tennessee State University.

21.Goldstein, L. (2007). Embracing Pedagogical Multiplicity: Examining Two Teachers' Instructional Responses the Changing Expectations Kindergarten in U.S. (ERIC Document Reproduction Service No. EJ773313).

22.Hargrave, O. (2003). We are all learning here: Project-based learning in the classroom. Unpublished master's thesis, Pacific Lutheran University.

23.Hedge, T. (2002). Teaching and Learning in the Language Classroom. Shanghai: Shanghai Foreign Language Education Press.

24.Helle, L., Tynjala, P., \& Olkinuora, E. (2006). Project-based learning in post-secondary education-theory, practice and rubber sling shots. Higher Education, 51(2), 287-314.

25.Herrington, A., \& Herrington, J. (2006). What is an authentic learning environment? In A. Herrington \& J. Herrington (Eds.), Authentic learning environments in higher education (pp. 1-14). Hershey, PA: Idea Group.

26.Johnson, C. (2003). A Perspective of the Effectiveness of Project Based Bilingual Curriculum in Personal Empowerment of the Adult English Language Learner: A Case Study. (ERIC Reproduction Services No. ED 482 588).

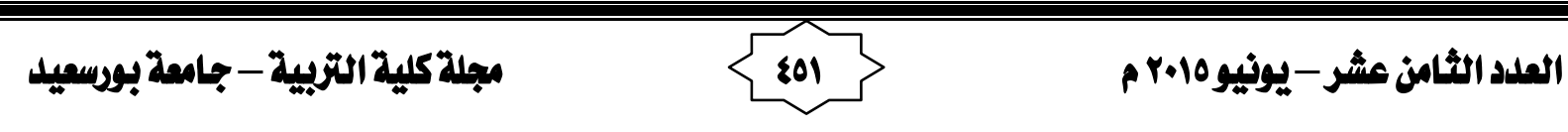


27.Kaderavek, J. ,\& Justice, L. M. (2002). Shared storybook reading as an intervention context: practices and potential pitfalls. American journal of speech-language pathology, 11(4), 395-405.

28.Ke, L. (2010). Project-based College English: An Approach to Teaching Non-English Majors. Chinese Journal of Applied Linguistics, 33(4), 99-112.

29.Khodary, A. (2010). The Effectiveness of A Proposed Micro Teaching Based Program on Developing English Teaching Skills for Pre - Service Female Teachers at Kindergarten. Unpublished doctoral dissertation, Al-Arish Faculty of Education, Suez Canal University.

30.Labbo, L. D. \& Field, S. L. (1996). Bookalogues: Oral language and language play. Language arts, 73, 618-625.

31.Li, D. (2000). Effect of story mapping and story map questions on the story writing performance of students with learning disabilities. Unpublished doctoral dissertation, Texas Tech University.

32.Markham, T., Mergendoller, J., Larmer, J., \& Ravitz, J. (2003). Project Based Learning Handbook. Canada: Buck Institute for Education.

33.Martin, K., \& Marmo, C. (1995). Use of a check-off system to improve middle school students' story compositions. Journal of Learning Disabilities, 28, 139-149.

34.Mcdonald, L. (2004) Moving from reader response to critical reading: developing 10-11-years-olds' ability as analytical readers of literary texts. Literacy, 38(1), 17-25

35.McGrath, D. (2002-2003). Launching a PBL Project. Learning \& Leading with Technology, 30(4), 36-39.

36. Meyers, K. (2008). A structured imagery intervention to improve students' narrative writing skills. Unpublished doctoral dissertation, Alfred University.

37.Morrow, L. M. (1996). Literacy and young children: Research-based practices. New York: Guilford.

38.Moss, D., \& Van Duzer, C. (1998). Project-Based Learning for Adult English Language Learners. (ERIC Reproduction Services No. ED 427 556).

39.Muniandy, B. (2000). An Investigation of the Use of Constructivism and Technology in Project-Based Learning. Unpublished doctoral dissertation, University of Oregon.

40.Newell, R. (2003). Passion for Learning: How Project-Based Learning Meets the Needs of 21st Century Students. Lanham: Scarecrow.

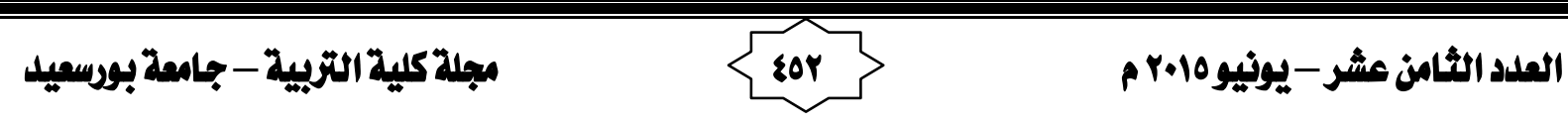


41.Patton, A. (2012). Work That Matters: The Teacher's Guide to ProjectBased Learning. The Paul Hamlyn Foundation.

42.Pennington, R.(2010). Using simultaneous promoting and promoting and computer assisted instruction to teach narrative writing skills to students with autism spectrum disorders. Unpublished doctoral dissertation, College of Education, University of Kentucky.

43.Petrosino, A. (2007). Houghton Mifflin College. Project-Based Learning. Retrieved January 20, 2015, from http://college.cengage.com/ education/resources/res_project/students/ c2007/index.html

44.Poonpon, K. (2011). Enhancing English skills through project-based learning. The English Teacher, 40, 1-10.

45. Retno Ayu, P. (2007). The use of animation movies for developing students' writing skill of narrative text. Semarang: Universitas Negeri Semarang.

46.Rubin, P. C. ,\& Wilson, L. (1995). Enhancing language skills in four and five year olds. Child and Family Canada. Retrieved September 19, 2013, from http://www.cfc-efc.ca/docs/cccf/00001046.htm

47.Sheppard, K., \& Stoller, F. (1995). Guidelines for the Integration of Student Projects into ESP Classrooms. Forum, 33(2), 10-23.

48.Silio, M. (2008). The effects of word prediction and text-to- speech technologies on the narrative writing skills of students with learning disabilities. Unpublished doctoral dissertation, International University.

49.Simpson, J. (2011). Integrating Project-Based Learning in an English Language Tourism Classroom in a Thai University. Unpublished doctoral dissertation, Australian Catholic University.

50.Solomon, G. (2003). Project-Based Learning: a Primer. Technology \& Learning, 23, 10- 20.

51.Srikrai, P. (2008). Project-based learning in an EFL classroom. Journal of Humanities and Social Sciences, 25, 85-111.

52.Sritiwong, U. (2000). Using School Newspaper Project to Promote English Writing Ability and Self-Efficacy of Mathayom Suksa 6 Students. Unpublished master's thesis, Chiang Mai University, Thailand.

53.Stanley, D. (2000). Project Based Learning- 6C's of Motivation. Retrieved January 15, from http://www.coe.uga.edu/epltt/Lesson Plans/LPPJL4DStanley.htm

54.Stoller, F. (1997). Project Work: A Means to Promote Language Content. Forum, 35(4), 2-20.

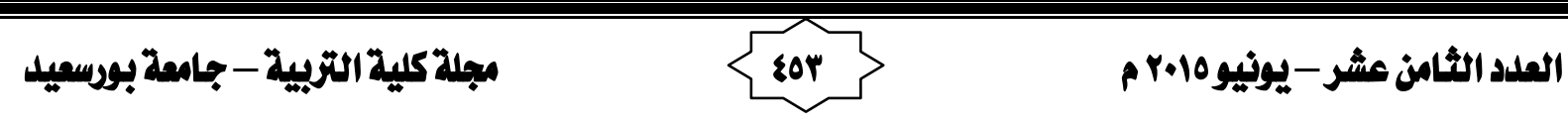


55.Stoller, F. (2002). Project Work: A Means to Promote Language and Content. In. J. Richards \& Willy, Renandya (Eds.), Methodology in Language Teaching: An Anthology of Current Practice (pp. 107-120). Cambridge: Cambridge University Press.

56.Stoller, F. (2006). Establishing a theoretical foundation for projectbased learning in second and foreign language contexts. In G. $H$. Beckett \& P. C. Miller (Eds.), Project-Based Second and Foreign Language Education: Past, Present, and Future (pp. 19-40). USA: Information Age Publishing.

57.Sudrung, J. (2004). A development of the Project-Based Process Curriculum to Enhance English Language Skills for the Upper Secondary School Students. Unpublished doctoral dissertation, Chulalongkorn University, Thailand.

58. Termprayoon, S. (2002). The Development of English Language Learning of Sixth Grade Students by Project Work Approach. Unpublished master's thesis, Silpakorn University, Thailand.

59.Vallecorsa, A., \& deBettencourt,L. (1997). Using a mapping procedure to teach reading and writing skills to middle grade students with learning disabilities. Education and Treatment of Children, 20, 173-188.

60.Vokuja, T. (2005). Cross Genre Approach to Short Stories. Retrieved on January 19, 2013, from http://www.ncte.org/pubs

61.Welsh, J. (2006). An Exploration of Project-Based Learning in Two California Charter Schools. Unpublished doctoral dissertation, University of Southern California.

62.Willie, S. (2001). Project based learning with multimedia. San Mateo County:

a. Office of Education.

63. Wrigley, H. (1998). Knowledge in Action: The Promise of ProjectBased Learning. Focus on Basics, 2 (D), 13-18.

Woo, Y., Herrington, J., Agostinho, S., \& Reeves, T. (2007). Implementing Authentic Tasks in Web-Based Learning Environments. Retrieved January 11, 2014, from http://www.educause.edu/EDUCAUSE +Quarterly/EDUCAUSE Quarterly Magazine Volum/ Implementing Authentic TasksinWe/161831

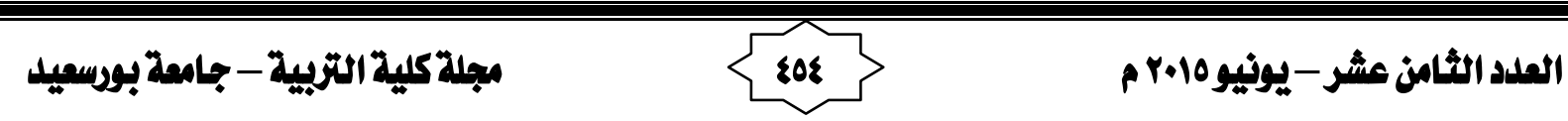

